\title{
Indian Journal of
}

\section{LANGUAGE AND LINGUISTICS}

\section{Echoic Communications and Pragmatic Relevance of COVID 19 Memes in Nigeria's Social Media Space}

\author{
Ambrose, Chinenye Lynda a (D), Idegbekwe, Destiny b, ${ }^{\text {, }}$ (i) \\ ${ }^{a}$ General Studies Unit, Western Delta University, Oghara, Delta State, Nigeria \\ ${ }^{b}$ Department of English, Faculty of Arts and Education,University of Africa, Toru-Orua, Bayelsa State, Nigeria \\ *Corresponding author Email: destiny.idegbekwe@uat.edu.ng \\ DOI: https://doi.org/10.34256/ijll2012
}

Received: 12-09-2020, Revised: 20-09-2020; Accepted: 22-09-2020; Published: 26-09-2020

Abstract: There are greater possibilities for a language utterance to have more meanings than what is stated. It is also possible for the hearers/audience to interpret what the speaker has in mind beyond what the speaker has put out in words. These meanings derived in this form are echoic and they are arrived at by choosing meanings that contextually relevant involving the least effort. How echoic relevant definitions are achieved has been studied using different language instances. Still, none in the researchers' knowledge has investigated how the COVID 19 social media memes, as used by Nigerians, communicate deeper meanings that are contextually relevant and how the echoic interpretations reveal the users' attitude. On this basis, therefore, the present study investigated the echoic nature of COVID 19 related social media memes as used by Nigerians. The study used Sperber and Wilson (1986) relevance theory as the theoretical framework and qualitatively analyzed Ten (10) purposefully selected memes. In the end, the study found out that interpretations of memes are significantly linked with the shared cognitive background knowledge which the speaker/meme creator and the hearer/audience have. Also, memes could echo the attitude of concern, disdain and fear while also harboring deeper meanings that contextually relevant and implicit.

Keywords: COVID 19, Memes, Relevance, Communication, Pragmatics, Echoic.

\section{Introduction}

If the process of communication was as simple as taking one's thoughts into the mind of another without any strains or changes in patterns, there would not have been any need devoting so much energy towards the study of communication and how language works in the real world. It is because, as Sperber and Wislon (1986) suggest, one would have been able to connect one's thoughts in words to the brain of the hearer just the way files are transferred from one computer device to the other. However, the process of communication is not that straightforward. In some instances, the speaker's thoughts never get to the hearer. In different situations, the speaker's thoughts are not explicitly reflected in words communicated to the hearer. In the later case, the hearer is left to use other means apart from the words to arrive at what the speaker had in mind. Whatever happens, to have a good communication act, Idegbekwe and Nwala (2016) note that there must be a convergence of three factors of the message sender, the message and the audience. That is to say, the three factors must be on the same page for meaningful communication, but the process through which this agreement is arrived at differ from one communication act to another.

As we have noted earlier, some instances of communication allow the hearers or audience to use 'other' means apart from the formal interpretations of the words used by the speaker to arrive at relevant interpretations. According to Wilson and Sperber (1995:1), 'Communication is a process involving two information-processing devices. One device modifies the physical environment of the other. As a result, the second device constructs representations similar to representations already stored in the first device.' Relating the above assertion to the present study, the first device (the speaker) is obliged to put across the message in a way in which it can be 
interpreted by the second device (the audience). The questions would then be what the speaker should do to be understood? Can everything be explicitly stated? How many words can one possibly use in communication to achieve comprehension?

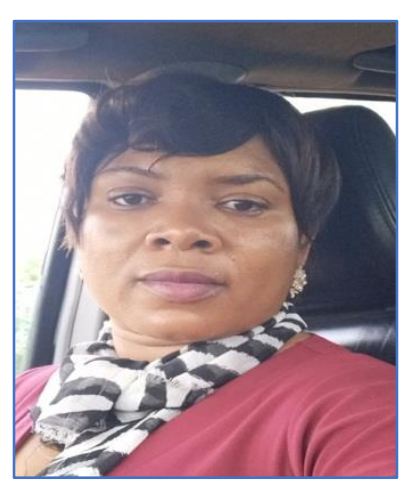

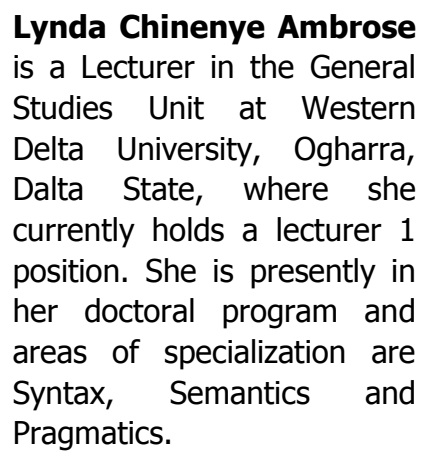

Lynda Chinenye Ambrose

is a Lecturer in the General Studies Unit at Western Delta University, Ogharra, Dalta State, where she currently holds a lecturer 1 position. She is presently in her doctoral program and Pragmatics.

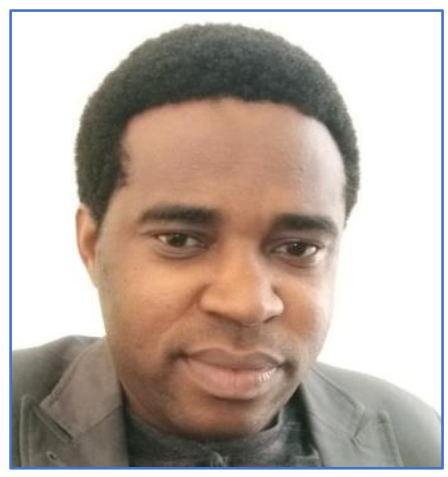

Idegbekwe, Destiny is a lecturer in the Department of English, Faculty of Arts and Education, University of Africa, Toru-Orua, Bayelsa State, Nigeria. He holds a Ph.D. in English Studies from the University of Port Harcourt, Choba, Rivers State, Nigeria. His areas of interest are ESL, Applied Linguistics, Discourse Study, pragmatics and Syntax.

In the real sense, speakers rarely say everything in their mind through words and the language instance which social media meme create is not an exception. If words are not used, there must be ways in which relevance is achieved. Even in cases in which words are used, the meanings in words may go beyond the tangible ways in which they are used. Any other meaning derived outside the meanings of the factual or literal words used is echoic. How echoic meanings are achieved has been studied using different language troupes and instances (cf. Idegbekwe and Kpuduwie 2018; Bryant 2012; Stanel 2006; Attardo 2000). However, how echoic pragmatic relevance is achieved in the researchers' knowledge has not been studied using social media meme as a language instance. This becomes more important because the nature of meme itself does not promote or permit the use of so many words in communication as pictures and other elements are needed for such interpretations. Hence, this study is critical because it could help unravel the ways (linguistic and paralinguistic) in which different meanings are arrived at using social media memes in Nigeria.

According to Attias (2017), the original 'meme' was first introduced by Richard Dawkins to explain how cultural information is disseminated. A meme refers to a funny image or a video shared on social media, which could present a situation contextually. Attias (2017) notes that the common use of the word "meme" usually refers to the "internet meme," a subset of the general meme concept. Most common internet memes are image macros photos with a bold caption written in Impact font. The text will usually be humorous or sarcastic. Memes as a language instant contain layers of meaning which are explainable in a different context. For this study's purposes, we have chosen memes that are contextually related to the COVID 19 pandemic and how they used for coded communications.

\section{Echoic relevance}

The relevance theory is a theory that is strongly linked with Grice's (1978) theory of conversation implications and meaning investigations. The relevance theory, in line with the Grecian world view, believes that 'that meaning is primarily a psychological phenomenon and only secondarily a linguistic one: for him, speaker's meanings are basic and sentence meanings are ultimately analyzable in terms of what speakers mean' (Wilson 2016: 1). According to Yus (2008: 3) the main hypothesis of the relevance theory is that humans are gifted with a biologically rooted ability to maximize incoming stimuli (linguistic utterances or nonverbal behavior). Relevance is a typical property of external stimuli (e.g. utterances) and internal representations and thoughts, all of which may become inputs for cognitive processing. Based on the above, the relevance theory proposes that in the process of communication, the hearer or the audience would search for meanings that are relevant and meet their expectations; once this is achieved, the hearer/audience would stop the search (cf. Nazir 2020).

The process of communication involves the speaker putting messages into codes that are mutually shared between different hearers. These codes are, in turn, interpreted by the hearers. This process is described in the figure below: 


\section{Coded communication}

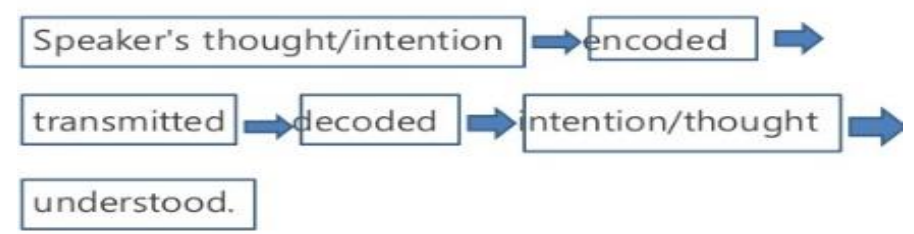

Figure 1 showing the struture/nature of coded information

Source: Nazir (2020:3).

In the interpretation and meaning generation process, the relevance theory believes that the hearer can arrive at a meaningful or relevant conclusion using assumptions contextually linked with the language utterance.

An echoic statement or instance of language use refers to language use that is subject to a different interpretation beyond the literal. It becomes relevant when it helps language users to achieve meaning that are contextually relevant and interpretable to the situation at hand. According to Sperber and Wilson (1986), a meaning interpretation of a linguistic utterance is appropriate when such an interpretation or assumptions, as they call it, are contextually relevant. In this case, the assumptions could be relevant or irrelevant, but it is a proper interpretation of the language utterance if it has excellent contextual relevance. To make this possible, the hearer or listener would use some premises related to the language utterance to derive some contextually interpretable implications.

The question in which such a consideration of meaning in context raises is usually related to the degree to which to consider the link between an assumption and a context. However, Sperber and Wilson (1986) are of the opinion that the degree and context considerations are tied to two concerns before concluding that an interpretation is relevant. According to them: 'relevance Extent condition 1: an assumption is relevant in a context to the extent that its contextual effects in this context are large. Extent condition 2: an assumption is relevant in a context to the extent that the effort required to process it in this context is small' (125). So, for the interpretations given to the meme considered in this study, they satisfy the two conditions. The first links the meme with the COVID 19 pandemic. There are different points to call at as mems reveal a lot of information about the COVID 19, which is a context of its own with a peculiar language context too to Nigeria. Also, arriving at the echoic interpretation is easy to conclude as too many explications are not needed. That is what Sperber and Wilson (1986) calls the assumptions with the least efforts.

Memes as an instance of language use deploy figurative language troupes that enable using few words and pictures with different layers of meanings. What unites representative examples of language use is that the thought (what the speaker had in mind) of the speaker, which is contextually interpreted by the language, can also be construed as an interpretation. It then becomes a meaning of someone who is not the speaker or the language instance creator. According to Sperber and Wilson (1986:231), these interpretations are 'second-degree interpretations: like all utterances, they first interpret a thought of the speaker, and it is only because this thought is itself an interpretation of someone else's thought that the utterance ultimately represents someone else's thought. Another way of making the same point is to say that an utterance used as an interpretation of someone else's thought is always, in the first place, an interpretation of one's understanding of that other person's thought.' When a meaning is achieved in this manner, one can say it is echoic.

\section{Methodology}

In terms of design, this study is qualitative. Denzin and Lincoln (2000: 3) opine that qualitative researches are interpretive and naturalistic. According to them, qualitative investigations dwell on things in their natural settings, attempting to make sense of, or interpret, phenomena in terms of the meanings people bring to them. In this study's context, the memes are analyzed based on how relevant they are in the COVID 19 pandemic context. 
Ten trending COVID 19 memes used by Nigerian social media users were purposefully picked from Facebook, Twitter, and WhatsApp posts and analysis status. The study could not choose a more significant number in a survey of this nature because of the space needed for a thorough investigation. In the data analysis, each meme was presented and analyzed to reveal the meme's echoic meanings and attitude that may be implicit or explicit but more implicit.

\section{Data Analysis}

In this section, we presented Ten (10) COVID 19 related memes used by Nigerians on the social media for analysis in line with how each of them is echoic for relevance.

\section{Meme 1}

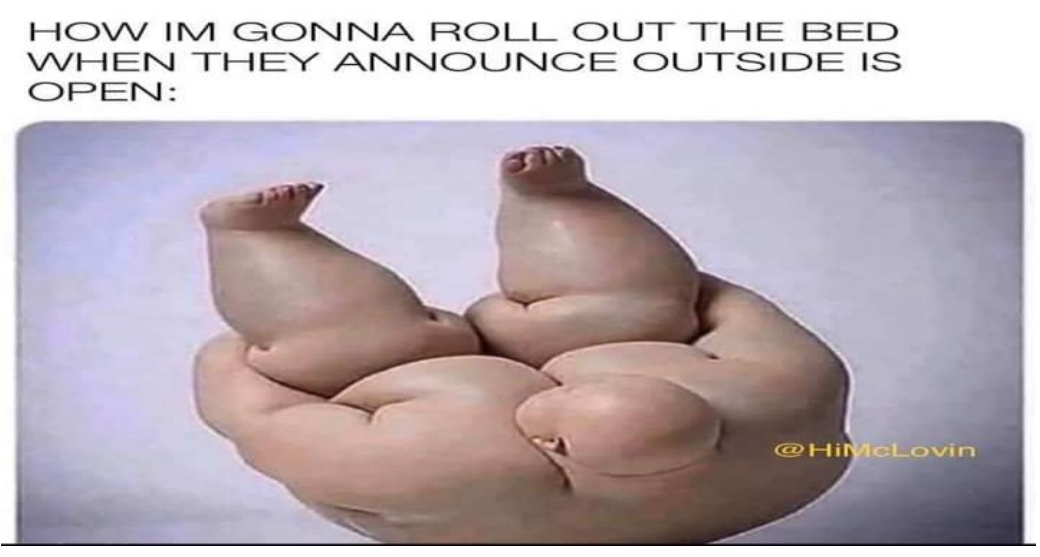

An echo is a sound that reverberates after it must have been spoken. Speaking in the context of meaning and relevance, the meme above resonates in the definition because all that is implied in the message are not all out in the meme itself. The other possible meanings echo on the knowledge of the hearer about the situation on the ground. The speaker's shared background knowledge (in this case, the meme creator) and the audience (the social media users) is essential in interpreting the message in the meme. The meme and the entire troupe of communication become relevant based on the hearer knowing that COVID 19 brought the idea of stay at home and this implies being sedate, which by extension could imply quick weight gain. This becomes more relevant based on the picture of the individual on the meme having a massive body structure having spent many days at home doing nothing.

In as much as the COVID, 19 pandemics is ravaging the world as the meme was used, the use itself echoes the attitude of humor and carelessness on few lines. The first is that the meme users do not really care so much about the health and economic effects of the pandemic. They being at home would have suggested they work from home or exercise or eat minimally to reduce the effects of such sedation. On the other hand, being at home could be boring. So, social media becomes an avenue to seek activities. These activities are mostly humorrelated, not just any kind of humor but humor that captures the moment's essence. As Sperber and Wilson (1986) note, an echoic communication could sometimes present the speaker's attitude, which could be left implicit, gathered only from the tone of voice, context and other paralinguistic clues; at other times, it may be made explicit. So, the idea of carelessness in weight gain is explicit because the idea of rolling out in a rather massive body is said in a very joyous and carefree tone. Then, the concept of humor is implicit in the exaggerated image of the weight gain. The idea is that even if people are to gain weight over the stay at home, it would not be this overbloated but for the sake of laughter, there is a suspension of unbelief.

\section{Meme 2}

The meme echoes the idea of sexual starvation on the part of the females due to the lockdown or stay at home caused by the COVID 19. The meme could have been interpreted as echoing a gender insult against the women as they are not the only ones who may have been starved of sex in the course of the lockdown but the use of the first person personal pronoun 'us' suggests that it was said by a lady. 

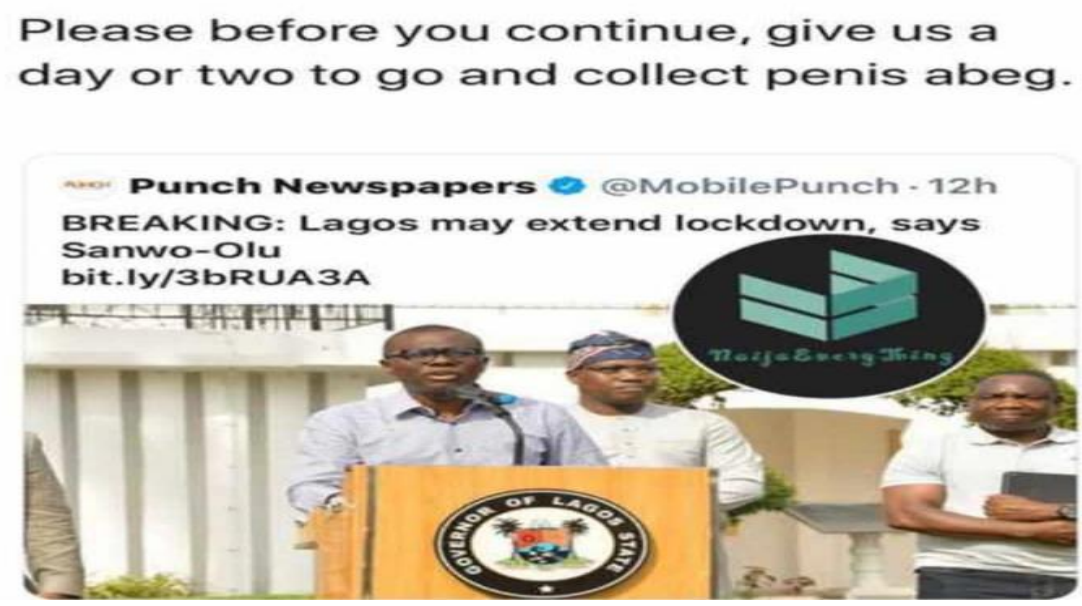

The anonymous nature of memes and in most cases the social media itself does not substantiate the argument of trying to seek the gender biasedness (cf. Konnikova 2013; Zhang and Kizilcec 2014). However, relying on the idea of interpreting the thoughts of the speaker in echoic utterances, the speaker intends to say that there is a need for a fresh air or freed. The meme echoes the idea of sexual starvation on the part of the females due to the lockdown or stays at home caused by the COVID 19. The meme could have been interpreted as echoing a gendered insult against the women as they are not the only ones who may have been starved of sex in the course of the lockdown but the use of the first person personal pronoun 'us' suggests that it was said by a lady. The anonymous nature of memes and, in most cases, the social media itself does not substantiate the argument of trying to seek the gender biasedness (cf. Konnikova 2013; Zhang and Kizilcec 2014). However, relying on the idea of interpreting the thoughts of the speaker in echoic utterances, the speaker intends to say that there is a need for fresh air or freedom after haven been on lockdown for two weeks already. In terms of attitude, there is partial approval of the lockdown for additional time, but it should not negate the personal needs of the individuals as adults in society. Hence, there is an appeal to the authority for a window for freedom before the extension of the lockdown. These meanings, as interpreted here, are relevant not on the basis of what is said but on the interpretation of the thoughts of the speaker and its echoes. If we are to follow the statement on the factual level, 'collect penis abeg' would mean to go and physically take 'penis.' Nobody does that in a sane society and the verb collect might go with it the reproductive part of the male. The echoic meaning interpreted here finds more illumination based on the fact that the Nigerian pidgin expression of 'I wan collect that girl/boy' has a sexual coloration beyond the idea of 'collect' as a Standard English word.

The attitude of humor is also implicit because many persons would not expect such a rather 'lousy' demand to be made to the State Governor in the middle of a great pandemic like the COVID 19. One would have expected the market to go shopping for food and essentials or attend to other medical needs. Such a shocking demand breeds humor and it is intentional to ease the tension of the period.

\section{Meme 3}

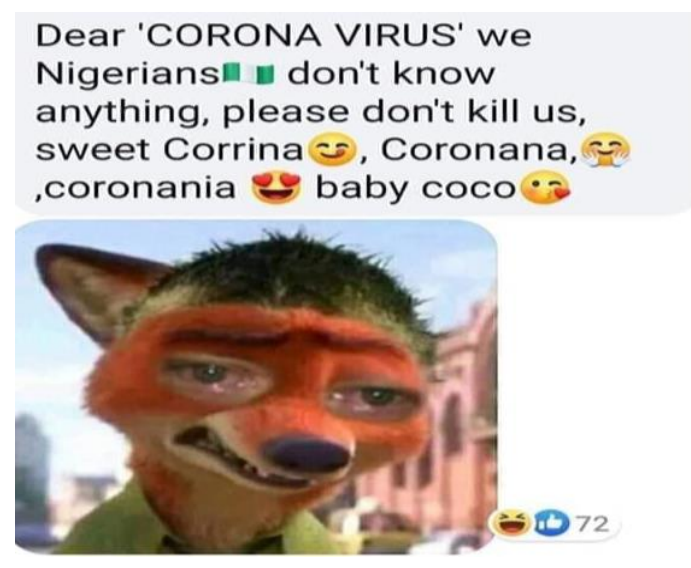


There is a sense of apostrophe here where Corona Virus is being addressed as an individual capable of listening to pleadings. That makes it funny or humorous. Pleading based on Nigerians' innocence alludes significantly to the various conspiracy theorists being canvassed by multiple sections of the world to have been the brain or the reason behind the virus's spread. Some say it was deliberately done by China to reduce America's influence on the world and its trade; others say it was a chemical weapon by the Americans to hurt China, but somehow boomerangs to the hit the USA and nations of the world. Others say the COVID 19 is significantly linked with installing $5 G$ network cables in some parts of the world. Olugbile (2020:3) notes that:

A rash of conspiracy theories has been spawned to explain and understand the disease. One of the early conspiracy theories was widely circulated in a gripping video... China was culling its citizens, committing mass murder on an industrial scale. Perhaps it was trying to reduce its population drastically.... The virus was a biological weapon, created in the laboratory by the Americans, and deliberately exported to China to cause havoc...Yet another theory had it that the Chinese developed the virus and were planning to export it as part of a trade war with the USA, which had seen the Americans imposing tariffs and victimizing the Chinese innovation flagship, Huawei.

If one examines all the theories of conspiracies presented above, honestly, Nigeria is not guilty in any of them. Nigeria is merely a victim of the entire pawn game. Meme 3 above echoes these thoughts. Since Nigeria is not responsible for any of the actions carried out to have brought the pandemic, the nation should be spared based on its innocence. On another plane, Meme 3 echoes Africans' nature, especially Nigerians, to the concept we find complex or challenging to comprehend. If it becomes too difficult to handle, it must be caused by higher spirits, which many believe can be addressed and pleaded to. On that basis, again, the speaker tries to praise COVID 19 by using expressions like 'sweet corrina', 'baby coco.' This is synonymous with how many African call God and gods 'sweet' names to get help from the supernatural.

Such a conspiracy can also be found in meme 4 below where there is an implicit allusion that the COVID 19 is a creation of the Chinese people and could be attached to anything related to China.

\section{Meme 4}

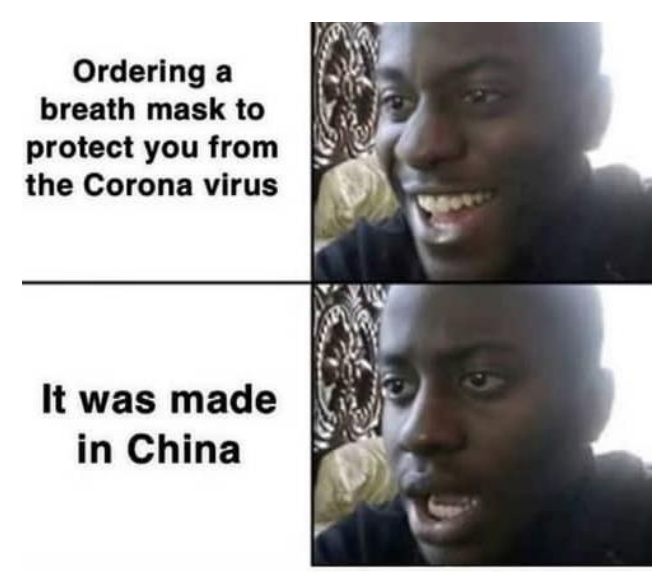

If one is to follow the conspiracies surrounding the COVID 19 to have been a Chinese made weapon, it would then be ironical to rely on them for the mask used for the protection. In the first picture in the meme, there seems to be excited about ordering a face protection mask because that is the right thing to do and before the outbreak, ordering from China would not have been a bad idea. However, on the realization of the present circumstances, the face changes to reflect the new awareness. In terms of attitude, it shows that the people buy into the conspiracy theory that COVID 19 is made from China and products from the country are no longer safe for use as they may be points to contract the disease.

\section{Meme 5}

The meme above represents one of the conspiracy theories behind the spread of the COVID 19 pandemic though we did not mention it in the explication of Meme 3. 


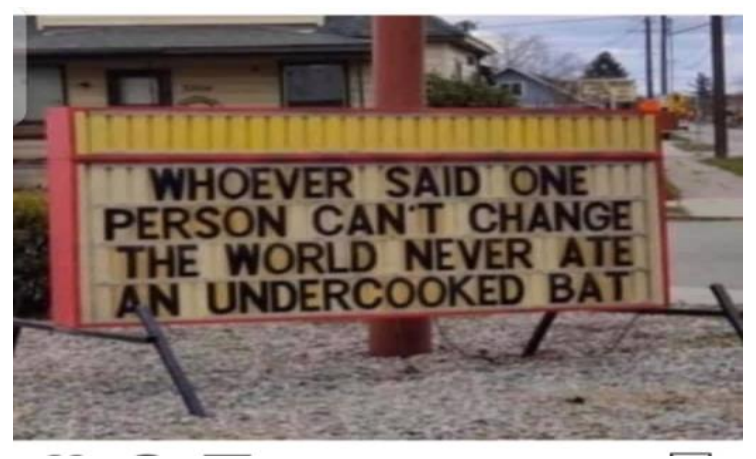

There are so many theories. One even attributes the pandemic to God being angry with man and wishes to deal with the 'sinful' man until he is on his knees begging. So, we would take at every point the conspiracy theories that enable a better interpretation of the meme in question. Many persons have since questioned the Chinese people's feeding habits since the outbreak of the COVID 19 disease. Many see the disease and other diseases such as Flu, Asian influenza, and others to have emerged from the nation due to eating of bats, frogs, cockroaches, and other scary items that the Chinese people are known to eat.

The meme echoes that no one took the dangers in such a feeding habit seriously until the outbreak of the pandemic disease. So, there is a need to pay attention to that saying that one person cannot change the world. In this case, a nation's feeding habit has changed the world drastically because it has brought a great pandemic. One person here could be extended to mean one country that eats uncooked bat. Just like the Ebola epidemic in Africa, there is a theory that COVID 19 has a link with the eating or the close associations of man and bat.

\section{Meme 6}
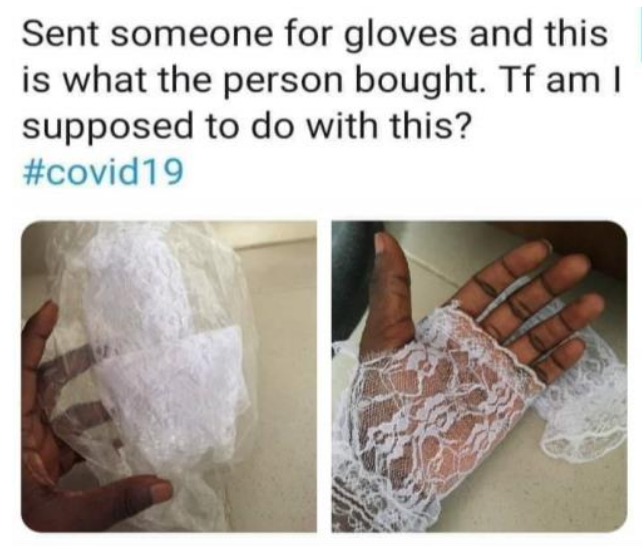

The above meme is a hilarious one but echoes the level of ignorance among many persons regarding the Personal Protection Equipment (PPE) needed to fight COVID 19. In this ignorance, many persons bought items that were not important. Some even went to the outrageous level of using polythene bags as protective items against the disease and many went as far as drinking hand sanitizers as a preventive measure. These all happened because there was no serious sensitization through the different media channels to the people on what to buy, eat and wear and what not to especially at the beginning of the spread in Nigeria. However, in terms of attitude to the meme, the speaker is surprised at interpreting the word 'gloves' to the individual and wishes to seek opinions from people (listeners), maybe rhetorically on what can be done using the kind of gloves bought.

\section{Meme 7}

The above meme came to the rescue when scientists found out that COVID 19 could be transferred through sex and hence warned people to stay off sex, but the funny meme above prescribes the type of sex that can be safe in the period and the dangerous one. The meme finds validation in the post made by the American Sexual Health Association (http://www.ashasexualhealth.org/sex-in-the-time-of-covid-19/) in which it stated that: 
In short-yes, you can still have sex, but with precautions. What do we know right now? This is a respiratory disease, so direct contact with saliva can transmit the virus. While COVID-19 has not been found in semen or vaginal fluid, it has been found in faces of infected people. As always, condoms and dental dams can reduce the risk and minimize contact with saliva and faces during anal and oral sex or oral/anal contact.

\section{Surviving Coronavirus}

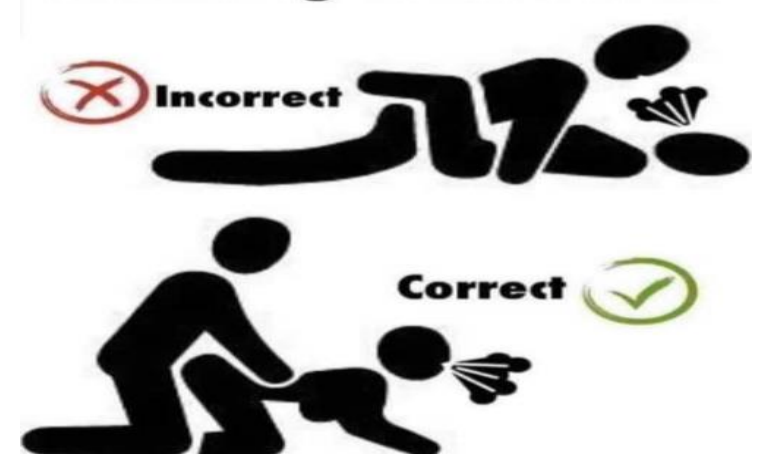

The first picture in the meme echoes the fact that COVID 19 is spread through the mouth and eyes. That type of sexual position that makes the two partners face each other is not approved because it portends danger; so, it is incorrect. On the other hand, picture 2 in meme 6 sees the female partner changing the position to the back; thereby prevent mouth and eye contact of the two persons in the sexual act. The meme echoes the fact that man is always looking to stay safe while still 'enjoying' all he needs to enjoy in the period of stay at home. However, both sexual positions are dangerous as both require close contact, which can spread the disease.

\section{Meme 8}

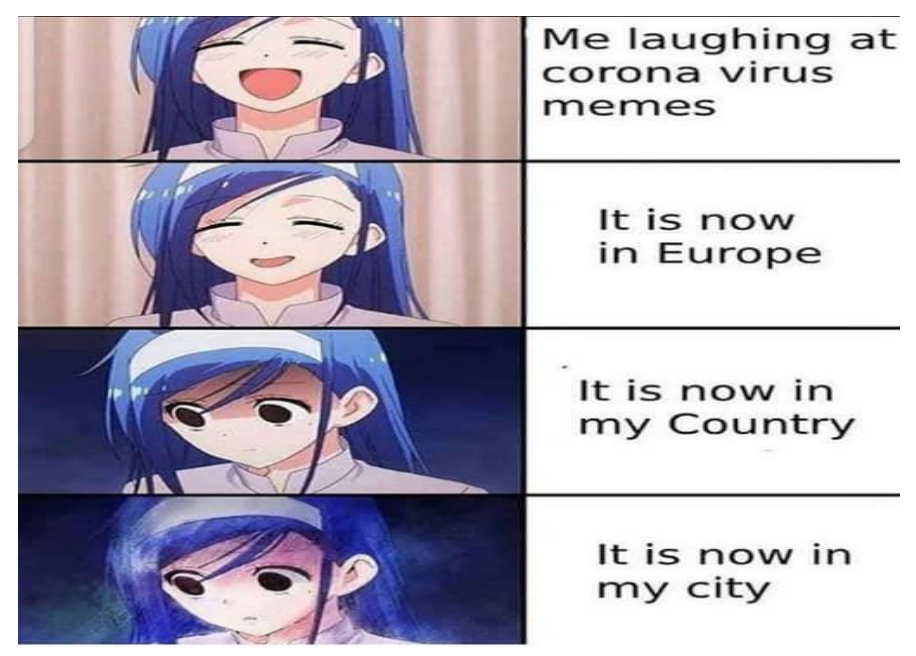

Meme 7 echoes the lack of concern that people paid to COVID 19 when initially in China. People from other parts of the world merely watched it as news items on television and they were indifferent to it even with the monumental figures/data of death rate. It was a laughing matter at that point because the death was not connected to the speakers in any way. It was a matter of data. Suddenly, it was in Europe and the apprehension shows itself for the first time as revealed in the changes in facial expression; then, the changes continue until it becomes a problem of the speaker's city. Now, the speaker is worried because it has been domesticated in his/her city. It shows how reactionary people have been with the pandemic. The danger which COVID 19 poses is only taken seriously when it is close by. This could justify why many African countries like Nigeria continued to allow people to fly in from countries with COVID 19 cases even against experts' advice. The idea was that it was happening in a far place, but within weeks, it was full of us in Nigeria. 


\section{Meme 9}

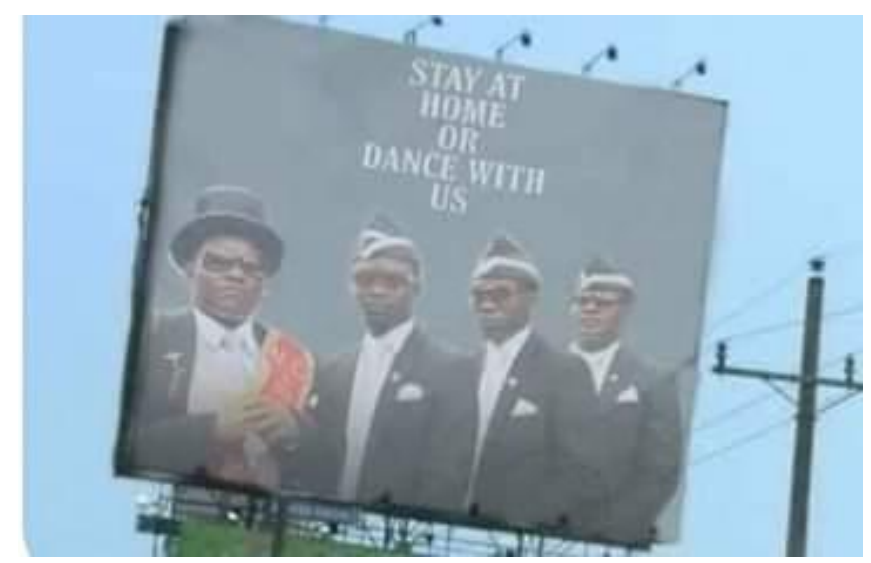

The echoic relevance of meme 8 is only interpretable if the right background knowledge exists in the hearers (audience) regarding the picture of the four men in the meme. The image portrays the dressing pattern of undertakers in Nigeria during burial processions and their performances could be dramatic. The undertakers in Nigeria are different, adding pomp and pageantry to the burial procession itself. They usually toss the casket around performing different acrobatic styles to the spectators' delight, who are usually thrilled at the ease with which the casket is thrown from side to side. The only way one can be part of this performance 'dance with us' is only in the coffin as a dead body. It is on that basis that the meme becomes relevant. The use of 'us' suggests that the undertakers themselves are speaking and ready to dance with those who choose to die. If the reader decides not to stay at home, he or she is toying with death. So, anybody outside this cognitive background information can actually not echo the meaning in the meme. It speaks volume of the fact that having shared background information is necessary for the interpretation of most figurative expressions, not just the irony and related troupes focused on by Sperber and Wilson (1986).

In terms of attitude, the meme shows that the speaker and the addressees fear death, and it is a strong appeal for the enforcement of the stay at home order in Nigeria. So the fear of dying becomes an instrument to reecho how dangerous the pandemic is. The use of 'or' subordinating conjunction kind of presents an option for the readers, but in the real sense, that is an option which the people would not want to choose ordinarily because it would be difficult to see a Nigerian in the right frame of mind choosing to die instead of staying at home.

\section{Meme 10}

\section{I don't care who your old man is. This gathering is illegal.}

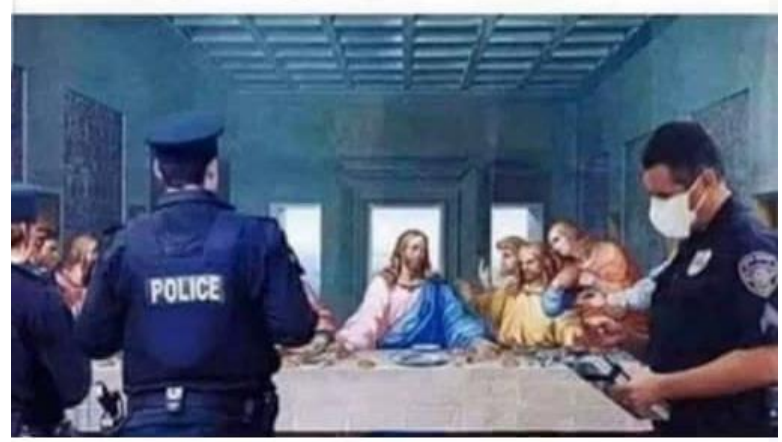

This meme echoes the stay at home order giving to individuals, places of worship, and other gatherings numbering more than 20 or 10 depending on Nigeria's state. As can be seen, the police are the chief enforcers of the law and are quite arrogant about the order. They represent the government, which makes laws and the law is not a respecter of persons. On the other hand, the popular image of Jesus with His disciples stands for places of worship which went ahead to defy the orders of the government for services and prayers not to hold. 
The attitude shown in the meme is that of disregard, disrespect, and abuse of the religious bodies in the nation with the stay at home law. The use of 'I don't care who your Old man is' has a very harsh tone that communicates disdain and contempt for such institutions that they represent. One may say in the time of crisis, there is no time for courtesies, but such actions have a way of saying we do not value what the religious institutions represent in the country.

\section{Discussion of Findings}

Memes like every instance of language use are relevant if the codes being used or relied on in the communication are shared by both the speaker and hearer. In this instance, the study found out that the echoic relevance of memes being used in Nigeria is significantly tied to the background information available to the interpreters. They may lose this echoic relevance if the right cognitive background knowledge is not shared between the speaker and the hearers. This finding validates the findings of Marmolejo-Ramos, et al. (2015). They discovered that evidence abounds that in language comprehension and neuroimaging studies of text comprehension, the shared background knowledge is as relevant as a source of information as the words in the text themselves. So, the book and the pictures are essential in interpreting the COVID 19 information for the memes. Still, if the relevant background knowledge is not available to decode this information, the echoic relevance would be lost or minimized to a great extent. As Alfaki and Siddiek (2013: 42) note, 'reading comprehension is attained through successful interaction between the reader and the text. This interaction is the major factor that plays the most important role in comprehension.' The reader in this case embodies what is being brought to the table by the hearers of meme for the interpretation of the texts and pictures in the meme.

Another finding from the analysis carried out above is the fact that memes have hidden meanings that can only be reechoed through a careful study or examination of the language use, as we have done above. This proves that what Sperber and Wilson (1986) note on the implicit nature of echoic language troupe is valid. The findings validate the fact that echoic relevance and interpretations go beyond the use of irony in languages. Many of the memes used instances of verbal irony but not all the memes. However, all the memes echo meanings beyond the explicit. It was Hamamoto (1998) and Yamanashi (1998) who took note of the fact that echoism in relevance could spurn beyond the use of irony. This finding was later further validated by Sperber and Wislon (1998).

Over the years, linguists have proved or demonstrated an association between language and attitudes either from the functional worldview of language (cf Halliday 1985; 1989; Halliday and Matthiessen 2004) or to a more social linguistic oriented language explanations (cf. Holmes 2008; Martin and White 2005; Umera-Okeke and Idegbekwe 2018). However, none in the researchers' knowledge has demonstrated the echo of attitude in the language troupes of memes. From the analysis carried out above, we have noted various attitudes such as arrogance, indifference, concern, humor, or abuse in the tone of the memes investigated. This is an expansion of the findings linking language and attitude.

\section{Conclusions}

This investigation concerned itself with how COVID 19 related social media memes used by Nigerians are contextually relevant. The relevance is in their ability to communicate deeper meanings beyond what is explicit and their ability to reveal the social, psychological and physical attitude to the pandemic. The study investigated Ten (10) of the memes and found out that memes' interpretations are significantly linked with the speaker/meme creator and the hearer/audience's shared background knowledge. Also, memes could echo the attitude of concern, disdain and fear while also harboring deeper meanings.

\section{References}

Alfaki, I. and Siddiek, A. (2013), The role of background knowledge in enhancing reading comprehension, World Journal of English Language, 3, 42-66. http://dx.doi.org/10.5430/wjel.v3n4p42

Attardo, S. (2000), Irony as relevant inappropriateness, Journal of Pragmatics, 32, 793-826. https://doi.org/10.1016/S0378-2166(99)00070-3 
Attias, C. (2017), Memes 101: what they are \& how to use them, https://www.wix.com/blog/2017/07/what-arememes Accessed 8 April, 2020.

Bryant, G. (2012), Is verbal irony special?, Language and Linguistics Compass, 6: 11, $=673-685$. https://doi.org/10.1002/Inc3.364

Denzi, N. and Lincoln, Y. (2011), SAGE Handbook of Qualitative Research, Dortmund: SAGE Publications.

Grice, H. (1978). Further Notes on Logic and Conversation, Syntax and Semantics Pragmatics, 9: 113 - 127.

Halliday, M. (1985), Introduction to functional grammar, London: Edward Arnold.

Halliday, M. (1989), 'Language and social meaning', International Conference on Humanities, historical and social sciences IPED, Singapore: IACSIT Press.

Halliday, M. and Matthiessen, C. (2004), An introduction to functional grammar, 3rd ed, London: Edward Arnold.

Hamamoto, H. (1998), Irony from a cognitive perspective In R. Carston \& S. Uchida (Eds.), Relevance theory: Applications and implications, Amsterdam: John Benjamins, pp. 257-270.

Holmes, J. (2008), An Introduction to sociolinguistics, London: Longman.

Idegbekwe, D. and Kpuduwei, A. (2018), Shared background knowledge as a prerequisite for ironic communication: An insight from Barack Obama's speech: Obama Out, The Journal of Communicative English, 18, 81-88.

Idegbekwe, D., and Nwala, M. (2016), Positive face strategies used in insurgency conversation: A focus on the PDP and the APC, Ikoku, 5:1, 44-49.

Konnikova, M. (2013), The psychology of online comments, The New Yorker, https://www.newyorker.com/tech/annals-of-technology/the-psychology-of-online-comment Accessed 9th April, 2020.

Marmolejo-Ramos, F., Elosúa de Juan, M., Gygax, P., Madden, C., and Mosquera Roa, S. (2015), Reading between the lines: The activation of embodied background knowledge during text comprehension, Pragmatics and Cognition, 5:11, pp. 211-241. https://doi.org/10.1075/pc.17.1.03mar

Martin, J. and White, P. (2005) The language of evaluation: Appraisal in English, New York: Palgrave Macmillan.

Nazir, K. (2020), Semantics and pragmatics the relevance theory, https://www.slideshare.net/kirannazir1/therelevance-theory-pragmatics Accessed 8 April, 2020.

Olugbile, F. (2020), 'Covid-19 and the Nigerian nation: An overview of the ongoing pandemic, the local response, and prospects for the future', Business Day Newspaper of 6th April, 2020, https://businessday.ng/coronavirus/article/covid-19-and-the-nigerian-nation-an-overview-of-theongoingpandemic-the-local-response-and-prospects-for-the-future/ Accessed 8 April, 2020.

Sperber, D. and Wilson, D. (1986), Relevance: Communication and cognition. Oxford: Blackwell.

Sperber, D. and Wilson, D. (1998), Irony and relevance: A reply to Seto, Hamamoto and Yamanashi In Carston, R. \& Uchida, S. (eds.) Relevance theory: Applications and implications, Amsterdam: John Benjamins, pp. 283293.

Stanel, T. (2006), Linguistic approaches to irony: An analysis of British newspaper comments. An unpublished Masters project of the linguistics department of Chemnitz University Technology.

Umera-Okeke, N. and Idegbekwe, D. (2018), A sociolinguistic analysis of selected Pentecostal proper names in Nigeria, The crab, 13, pp.83-93.

Wilson, D. (2016), Relevance Theory, in.Y. Huang (ed), Oxford Handbook of Pragmatics, London: Oxford University Press, pp. 343-386. https://doi.org/10.1093/oxfordhb/9780199697960.013.25

Wilson, D. and Sperber, D. (1995), Relevance: Communication and Cognition, Cambridge: Blackwell. 
Yamanashi, M. (1998), Some issues in the treatment of irony and related tropes In R. Carston \& S.Uchida (Eds.), Relevance theory: Applications and implications, Amsterdam: John Benjamins, pp. 271-281.

Yus, F. (2008), Relevance Theory, https://personal.ua.es/francisco.yus/site/ELL2.pdf Accessed 8 April, 2020.

Zhang, K. and Kizilcec, R. (2014), Anonymity in social media: effects of content controversiality and social endorsement on sharing behavior, Conference', Eighth International AAAI Conference on Weblogs and Social Media

\section{Funding}

No funding was received for conducting this study.

\section{Conflict of interest}

The authors have no conflicts of interest to declare that they are relevant to the content of this article.

\section{About The License}

(C) The author(s) 2020. The text of this article is open access and licensed under a Creative Commons Attribution 4.0 International License 